\title{
Ecological and phytocenotic characteristics of plant communities of Nitraria schoberi L. in Dagestan.
}

\author{
Magomed Gadzhiataev * , and Zagidat Abdurakhmanova \\ Mountain botanical garden DFRC RAS, 367000, 45, M. Hajiyev str., Republic of Dagestan, \\ Makhachkala, Russian Federation
}

\begin{abstract}
For the first time, an ecological-phytocenotic classification of communities of Nitraria schoberi L., widespread in the territory of the Republic of Dagestan has been developed. 29 geobotanical descriptions were carried out on sample plots (SP) taking into account the floristic composition, as a result of which 7 formations, 14 groups of associations and 27 associations were identified. In the course of research, 179 species of higher vascular plants were identified in communities with the participation of Nitraria schoberi. The largest was the Nitrarieta schoberi formation with 7 groups of associations and 14 associations, in which 128 species of vascular plants grow.
\end{abstract}

\section{Introduction}

Increased unsystematic use of natural resources, disturbance of the condition of pastures and other negative factors contribute to the emergence of many environmental problems, in particular the process of desertification.

In this regard, it became necessary to study communities with the participation of the Red Data Book species Nitraria schoberi in Dagestan, one of the few fruits and berry plants capable of growing on salt marshes and well tolerating being covered with sand, which is a natural sand-strengthening agent. Modern studies on the study of communities with the participation of Nitraria schoberi are given in works E.V. Mavrodiev et all., I.A. Rukhlenko, E.V. Banaev et all., I.A. Goryaev [1-6].

\section{Methods}

The work used materials and collections of field research carried out in 2015-2018. as part of expeditions. In communities with the participation of Nitraria schoberi, test plots of $20 \times$ $20 \mathrm{~m}$ were laid. The test plots were tied to a geographic grid using a personal GPS radio navigator. The names of syntaxa are given in accordance with the Code of phytosociological Nomenclature [7].

\footnotetext{
*Corresponding author: zagidat.abdurahmanova88@mail.ru
} 
Taxonomic affiliation and nomenclature of species are given according to the «Conspectus of the flora of Dagestan» [8], «Conspectus of the flora of the Caucasus» [9], when identifying rare and protected species, «Red Book of the Republic of Dagestan» [10] and «Red Book of the Russian Federation» [11] were used.

\section{Results}

Based on the materials of geobotanical studies processed by the ecological-phytocenotic method of communities with the participation of Nitraria schoberi in Dagestan 5 formations, 12 groups of associations and 25 associations were identified:

Classification scheme

Formation Nitrarieta schoberi

Group of associations Artemisieta tschernievianae

Ass. Artemisietum tschernievianae nitrariosum schoberae

Group of associations Botriochleta ischaemae

Ass. Cladiumetum martii botriochlosum ischaemae

Ass. Nitrarietum schoberae botriochlosum ischaemae

Group of associations Botriochleta ischaemae-herbosa

Ass. Botriochletum ischaemae nitrariosum schoberae

Ass. Teucriumietum polium elaeagnoso-nitrariosum schoberae

Ass. Rhamnetum pallasii botriochloso-nitrariosum schoberae

Group of associations Artemisieta Lerchianae

Ass. Nitrarieto-artemisetum lerchianosum

Ass. Rhamnetum pallasii artemisieto lerchianoso-nitrariosum schoberae

Ass. Artemisietum lerchianae nitrarioso schoberae - anizanthosum

tectorum

Group of associations Artemisieta Marshallianae

Ass. Artemisietum marshallianae

Ass. Botriochleto-nitrarieto-artemisetum marshallianae

Ass. Nitrarieto-artemisetum marshallianae

Ass. Artemisietum marshallianae parietarioso-nitrariosum schoberae

Group of associations Artemisieta santonicae - nitrarieta schoberae

Ass. Artemisietum santonicae nitrariosum schoberae

Formation Artemisieta austriacae

Group of associations Artemisieta austriacae-fruticosa

Ass. Salsoleto-colutieto-artemisietum austriacae

Formation Artemisieta tauricae

Group of associations Artemisieta tauricae-fruticosa

Ass. Fruticuleta-artemisetum tauricae

Group of associations Artemisieta tauricae

Ass. Tamariceta-artemisietum tauricae carecosum humilis

Ass. Tamaricetum laxae artemisiosum tauricae

Ass. Calamagrostidetum caucasicae noaeoso- artemisiosum tauricae

Ass. Capparicetum herbaceae artemisiosum tauricae

Formation Artemisieta santonicae

Group of associations Artemisieta santonicae

Ass. Noaeta macronata artemisiosum santonicae

Formation Tamariceta laxae

Group of associations Tamariceta laxae

Ass. Artemisietum tauricae tamaricosum laxae 


\section{Group of associations Medicageta minimae \\ Ass. Tamaricetum laxae medicagosum minimae \\ Ass. Tamaricetum laxae graminoso-medicagosum minimae}

\subsection{Formation Nitrarieta schoberi}

Nitraria schoberi L. - halophytic shrub, xerophyte. The range of the species Nitraria schoberi L. is mainly made up of the Caspian and Turan lowlands, where saltpeter is found in large quantities. In the north, its distribution is limited by the line: $56^{\circ} \mathrm{N}(\mathrm{Omsk})$; in the west, it is known in Ergeny, on the territory adjacent to the Caspian Sea. Also, in the west are its severed locations in the eastern Crimea near Sudak, as well as in the Lower Danube lowland. The distribution area of Nitraria schoberi (according to literature data) is the Caucasus, Central Asia, Western Siberia, Iran and Western China [12-15]. There is an indication of the growth of Nitraria schoberi in the Ploiesti region of Romania in the "Flora of Romania" [16]. Its range covers the entire Ordos, the Alashan Desert, partly the Mongolian Gobbi, the foothills and low mountains of the Nan Shan and Altyn Taga, the eastern outskirts of the Tsaidam Basin with the surrounding foothill plains [17, 18]. In the east it reaches the regions of Kashgar and Dzungaria. In the south, the range of N. schoberi reaches Afghanistan; so far only one locality is known (Khusan on Gerirud) [19].

The total projective cover in Nitraria schoberi in the shrub layer varies from 5 to $50 \%$, and in the herbaceous layer from 10 to $45 \%$.

The species composition of the communities of the Nitraria schoberi includes 129 species of higher vascular plants. In communities, species of the genus Tamarix often codominated. With saline soils, hyperhalophytes of Halimione verrucifera are abundant in them, less often Halocnemum strobilaceum and Nitraria schoberi.

In cenoses, the main place is occupied by species of the genus Artemisia (A. austriaca, A. santonica, A. marshalliana, A. lercheana, A. tschernieviana, A. annua), Anizantha rubens, Poa bulbosa, and Botriochloa ischaemum.

Based on our own descriptions, we carried out an ecological-phytocenotic classification of communities of the Nitrarietae schoberi formation, widespread in the Republic of Dagestan. It includes 6 groups of associations and 14 associations.

\subsubsection{Group of associations Artemisieta tschernievianae}

The group of associations Artemisieta tschernievianae is rare, on the sandy ridges of the coastal lowland. The projective cover of the shrub layer is about $40 \%$, of the herbaceous layer up to $25 \%$.

Tamarix laxa together dominates in the layer of shrubs together with Nitraria schoberi. Communities of this group of associations include Cynanchum acutum, Plantago scabra, Daucus carota, Eryngium campestre, Anthemis ruthenica, Eremostachys laciniata, Syrenia siliculosa, Jurinea ciscaucasica.

\subsubsection{Group of associations Botriochleta ischaemae}

The group of associations Botriochleta ischaemae occurs on the rock taluses of Inter Mountain Dagestan. The projective cover of the shrub layer is $10 \%$, herbaceous layer is about $30 \%$.

Along with Nitraria schoberi, in the communities of this class of associations, the background species of the shrub layer are Clematis orientalis, Tamarix smyrnensis, Paliurus spina-christi, and Rosa pimpinellifolia. The herbaceous layer is dominated by Cladium martii, Artemisia incana, A. marshalliana, Cynanchum acutum, Parietaria 
judaica, Gypsophila capitate. The constant species for this class of association are Euphorbia virgata, Galium brachyphyllum, Solanum dulcamara, Satureja subdentata, Salvia canescens.

\subsubsection{Group of associations Botriochleta ischaemae-herbosae}

Communities of the Botriochleta ischaemae-herbosae group of associations are found near saline lakes, hydrogen sulfide springs and depressions in the coastal part of the Primorskaya plain of Dagestan, on salt licks. The projective cover of the shrub layer varies from 25 to $50 \%$, and of the grass layer $20-30 \%$.

In the ravines of a temporary watercourse on the coastal part, the role of the background species, along with Nitraria schoberi, is assumed by Elaeagnus angustifolia, and at the outcrops of limestone plates, Rhamnus pallasii. The main dominants of the herbaceous layer are xero-holophytic perennials Artemisia santonica, A. annua, Limonium mejeri, Plantago scabra, Galium aparine, Teucrium polium, and Eryngium caucasicum.

\subsubsection{Group of associations Artemisieta lerchianae}

The group of associations Artemisieta lerchianae are found near salt lakes, in depressions of the Caspian lowland with a high groundwater table, on sands. The projective cover of the shrub layer is from 10 to $40 \%$, and of the herbaceous layer $15-45 \%$.

In the group of associations Artemisieta lerchianae, the background species of the shrub layer is Nitraria schoberi in rare cases, Rhamnus pallasii can be a together dominates. In the grass layer, the role of dominants in the communities located near salt lakes is assumed not only by Artemisia lercheana, but also by Plantago lanceolata, Galium aparine, Artemisia austriaca, Botriochloa ischaemum, and in the depressions of the Caspian lowland Anizantha rubens and Poa bulbosa. The constant species of this class of associations are Artemisia lercheana, Agropyron pectinatum, Medicago caerulea, Asparagus officinalis.

\subsubsection{Group of associations Artemisieta marshallianae}

Communities of the group of associations Artemiseta marshallianae are more often found on dry slopes with outcrops of salts, in ravines with a temporary watercourse. The projective cover of the shrub layer is from 5 to $12 \%$, and of the herbaceous layer is $10-25 \%$.

In the shrub layer of this of associations, the main dominant is Nitraria schoberi, in rare cases, Clematis orientalis. The main feature of the herbaceous layer is the occurrence of tap-root perennial plants Convolvulus arvensis, Artemisia marshalliana, Parietaria judaica, Gypsophila capitata, Erysimum meyerianum, Euphorbia virgata. Among cereals, Botriochloa ischaemum is a codominant.

\subsubsection{Group of associations Artemisieta santonicae - nitrarieta schoberae}

Communities of the group of associations Artemisieta santonicae - nitrarieta are rare, near saline lakes and depressions on salt licks. The projective cover of the shrub layer is up to $35 \%$, and that of the herbaceous layer is up to $20 \%$.

The background species of the shrub layer is Nitraria schoberi, and Teucrium chamaedrys, Eryngium caucasicum, and Centaurea squarrosa dominate in the herbaceous layer along with Artemisia santonica. Among cereals Botriochloa ischaemum and Bromus briziformis are together dominates. 


\subsection{Formation Artemisieta austriacae}

Artemisia austriaca Jacq. - halophyte, with a creeping adventitious root system. The range of the species stretches from the territory of the Caucasus, Central Asia, Iran, Ukraine, Moldova, Crimea, Belarus to Northwest China. For the growth of Artemisia austriaca prefers old fallow lands, forest-steppe and steppe zones, alkaline meadows, pastures, steppe and steppe slopes.

The total projective cover in the communities of the Artemisia austriaca and in the shrub and grass layers reaches $40 \%$.

The species composition of the Artemisia austriaca communities is very poor and includes up to 10 species of higher vascular plants. This is due to the fact that the soil is subject to water and wind erosion, so ephemeroids and annuals do not take root.

In these communities, the main place is occupied by the species Artemisia austriaca and Carex humilis, and among the shrubs Nitraria schoberi, Colutea orientalis, and Salsola daghestanica.

Based on our descriptions, an ecological-phytocenotical classification of communities of the Artemisietae austriacae formation, widespread in the Republic of Dagestan, was carried out. It includes 1 group of associations and 1 association.

\subsubsection{Group of associations Artemisieta austriacae-fruticosa}

Communities of the Artemiseta austriacae-fruticosa group of associations occur on dry slopes with loose shale, subject to constant water and wind erosion. The projective cover both in the shrub and grass layers reaches $40 \%$. Colutea orientalis and Salsola daghestanica are the background species of the shrub layer, together with Nitraria schoberi; in the herbaceous layer Carex humilis codominates with Artemisia austriaca.

\subsection{Formation Artemisieta tauricae}

Artemisia taurica Willd. - a perennial plant with a rod thick, upright, woody root system. Occurs from Crimea in the west to the Bogdinsko-Baskunchaksky nature reserve in the Astrakhan region in the east. On the territory of the range, Artemisia taurica is distributed intermittently, and it is classified as a rare plant. However, at present, this Artemisia taurica is expanding its range, actively spreading over fallows in the south of the steppe zone and in the desert zone [20].

The total projective cover in communities of Artemisia taurica in the shrub layer varies from 8 to $40 \%$, and in the herbaceous layer from 20 to $50 \%$.

The Artemisia taurica communities are rich in species composition, including 59 species of higher vascular plants. The background species in the communities of this formation are Nitraria schoberi, Spiraea hypericifolia, Colutea orientalis, Salsola ericoides, Salsola daghestanica, Rhamnus pallasii, Tamarix ramosissima. The main dominants of the herbaceous layer are Artemisia taurica, Iris timofejewii, Noaea mucronata, Halimione verrucifera, Carex distans, Calamagrostis caucasica, Phleum phleoides, Capparis herbacea.

Based on the results of our own descriptions, we carried out an ecologicalphytocenotical classification of communities of the Artemisietae tauricae formation widespread in the Republic of Dagestan, which includes 2 groups of associations and 6 associations. 


\subsubsection{Group of associations Artemisieta tauricae-fruticosa}

Communities of the group of associations Artemisieta tauricae-fruticosa occur on dry slopes with loose shale, subject to constant water and wind erosion in the ravines of a temporary watercourse. The projective cover of shrub and grass layers reaches $40 \%$.

In the group of associations Artemisieta tauricae-fruticosa, the background species of the shrub layer is Nitraria schoberi, Spiraea hypericifolia, Colutea orientalis, Salsola ericoides, Salsola daghestanica. Rhamnus pallasii and Cerasus incana are also found. In the herbaceous layer, Artemisia taurica is the main dominant species. Medicago caerulea, Iris timofejewii, and Artemisia salsoloides are often found in such communities.

\subsubsection{Group of associations Artemisieta tauricae}

The group of associations Artemisieta tauricae is found on heavily eroded shale slopes in the ravines of a temporary watercourse, as well as on salt marshes with a salt crust, on the shores of salt lakes. The projective cover of the shrub layer is from 8 to $20 \%$ and of the herbaceous layer is from 20 to $50 \%$.

In the Artemisieta tauricae group of associations, the background species of the shrub layer are Nitraria schoberi and Tamarix ramosissima. Tamarix laxa, Atraphaxis daghestanica are rare.

In the herbaceous layer, the dominant communities of this class of associations located on the shale slopes in the ravines of the temporary watercourse are played by the species Medicago caerulea, Convolvulus arvensis, Capparis herbacea, and Artemisia marshalliana. The communities of the class of associations Artemisieta tauricae located along the shores of salt lakes are dominated not only by Artemisia taurica, but also by Noaea mucronata, Halimione verrucifera, Carex distans, Calamagrostis caucasica, Phleum phleoides.

\subsection{Formation Artemisieta santonicae}

Artemisia santonica L. is a halophytic perennial plant with a rod-and-root system. The range of the species is the Black Sea-Northwest Caspian, it stretches from the Black Sea region $\left(33^{\circ} \mathrm{E}\right)$ in the west, to North-Western Kazakhstan $\left(45^{\circ} \mathrm{E}\right)$ in the east. The northern border reaches $52^{\circ} \mathrm{N}$, the southern one $-44^{\circ} \mathrm{N}$. [21]. Artemisia santonica is a desert-steppe species $[22,23]$.

The projective cover of the shrub layer is up to $10 \%$, of the grass layer is $30 \%$.

The species composition community of the Artemisia santonica is scanty (10 species of higher vascular plants). The communities are often dominated by shrubs of Nitraria schoberi and species of the genus Tamarix. In the herbaceous layer, the main role is played by Artemisia santonica, Noaea mucronata, Halimione verrucifera.

Based on the results of our own descriptions, we carried out an ecologicalphytocenotical classification of communities of the Artemisieta santonicae formation, widespread in the Republic of Dagestan, which includes 1 group of associations and 1 association. 


\subsubsection{Group of associations Artemisieta santonicae}

Communities of the Artemisieta santonicae group of associations are found on salt marshes along the shores of salt lakes of the coastal plain. The projective cover of the shrub layer reaches $10 \%$, of the herbaceous layer $30 \%$.

The background species of the shrub layer is Nitraria schoberi and Tamarix ramosissima, rarely Salsola glauka. The main dominants in the communities of the group of associations Artemisieta santonicae are Artemisia santonica, Noaea mucronata. These communities also contain Artemisia taurica, Alhagi pseudalhagi, Gypsophila paniculata, and one of the hyperhalophytes, Halimione verrucifera, is often found.

\subsection{Formation Tamariceta laxae}

Tamarix laxa Willd. - a large, highly branched shrub or in the form of a small tree up to 5 $\mathrm{m}$ tall. Grows in the lower reaches of the Volga, Central Asia, Mongolia, Northwest China, Northern Iran, Afghanistan. In Dagestan, it grows on the Terek-Sulak lowland to the lower mountain belt [7]. It is very unpretentious to soil conditions, tolerates salinity well, and is insensitive to drought. It is used in single and group plantings as an ornamental and sandfixing plant in the south and southeast of the European part of Russia.

The projective cover of the shrub layer varies from 10 to $35 \%$, and of the herbaceous layer from 25 to $55 \%$.

The species composition of the communities of this formation includes 40 species of higher vascular plants. The communities are often dominated by shrubs of Nitraria schoberi and species of the genus Tamarix laxa. In the herbaceous layer, the main role is played by Artemisia taurica, Medicago caerulea, Medicago minima, Leymus racemosus, Poa bulbosa, Hordeum leporinum, Silene conica, Aira notarisiana, Carduus cinerus.

Based on the results of our own descriptions, we carried out an ecologicalphytocenotical classification of communities of the Tamariceta laxae formation, widespread in the Republic of Dagestan, which includes 2 groups of associations and 3 associations.

\subsubsection{Group of associations Tamariceta laxae}

Communities group of associations Tamariseta laxae are found on the Terek-Sulak lowland to the lower mountain belt, on sands and salt marshes.

The projective cover of the shrub layer is $35 \%$, of the grass layer $25 \%$. In the group of associations Tamariceta laxae, the background species of the shrub layer is Nitraria schoberi, Tamarix laxa, Salsola glauka. Artemisia taurica, Leymus racemosus, Medicago caerulea, Frankenia hirsuta, Phleum phleoides take on the role of dominants of communities of this class of associations in the herbaceous layer.

\subsubsection{Group of associations Medicageta minimae}

The group of associations Medicageta minimae is found on the salt marshes of the TerekSulak lowland to the lower mountain belt.

The projective cover of the shrub layer ranges from 10 to $20 \%$, and of the herbaceous layer from 50 to $55 \%$. In the communities of this group of associations, the background species of the shrub layer are Nitraria schoberi and Tamarix laxa. In the herbaceous layer Medicago minima, Medicago caerulea, Poa bulbosa, Hordeum leporinum, Silene conica play the main role. There are also Artemisia taurica, Anthemis ruthenica, Leymus racemosus, Bromus commutatus, Aira notarisiana, Melandrium album, Carduus cinerus, Asparagus officinalis. 


\section{Discussion}

According to the conducted studies using the ecological-phytocenotical method of communities with the participation of Nitraria schoberi 5 formations, 12 groups of associations and 25 associations were identified in Dagestan.

The formation of the Nitrarieta schoberi (128 species) is characterized by the greatest floristic diversity. The Artemisieta tauricae (59 species), Tamariceta laxae (40 species) are diverse. The Artemisieta santonicae (11) and Artemisieta austriacae (8) formations are much inferior in species diversity.

No one has studied the communities with the participation of Nitraria schoberi on the territory of Dagestan. Work was carried out to study a similar flora using the ecologicalphytocenotical method on the territory of Kalmykia [4, 23]. Studies have also been carried out from the standpoint of the ecological-floristic approach to study the communities of steppe vegetation where Nitraria schoberi directly grows [24-26]. Based on the results of both their own studies and the results of other authors, it is necessary to carry out a comparative assessment of the species richness of communities with the participation of Nitraria schoberi.

\section{Conclusion}

There are many species in need of protection in the populations of Nitraria schoberi, which have a high phytosociological value, as they are represented by rare and endemic vegetation types of Dagestan.

For the first time, an ecological-phytocenotic classification of communities with the participation of Nitraria schoberi widespread in the Republic of Dagestan has been developed. The current state of these communities with the participation of the Dagestan Red Data Book species Nitraria schoberi at the present time remains unsatisfactory. On the basis of the classification, more valuable and rare communities will be recommended, the study and monitoring of which will allow preserving and predicting the further development of areas that are on the verge of extinction and are subject to constant anthropogenic pressure.

\section{References}

1. E.V. Mavrodiev, A. P. Laktionov, Nico Cellinese, Ecology and Evolution, 7, 2 (2012)

2. I.A. Rukhlenko, Proceedings of the Samara Scientific Center of the RAS, 25, 2 (2008)

3. L.P. Mironova, V.G. Shatko, Geopolitics and ecogeodynamics of regions, 9, 2 (2013)

4. I.A. Goryaev, A.P. Korablev, Contemporary Problems of Ecology, 13, 5 (2020)

5. E.V. Banaev, M.A. Tomoshevich, M.S. Voronkova, Journal of Plant Science and Conservation, 7, 1 (2018)

6. E.V. Banaev, M.A. Tomoshevich, T.A. Ak-Lama, Contemporary problems of Ecology, 14, $3(2021)$

7. H.E. Weber, J. Moravec, J.-P Theurillat, Journal of Vegetation Science, 11, 5 (2000)

8. R.A. Murtazaliev, Epoch Publishing House, 1 (2009)

9. Conspectus of the flora of the Caucasus (Publishing house S.-Petersburg University, 2012)

10. Red Book of the Republic of Dagestan (Printing house A4, 2020)

11. Red Book of the Russian Federation (Plants and Fungi) (KMK Scientific Press, 2008)

12. Q. Dong, N. Hu, Y. Suo, X. Chi, H. Wang, Mitochondrial DNA Part B, 4, 1 (2019)

13. H. Akhani, Edinburgh Journal of Botany, 59, 2 (2002) 
14. J. Sharifi-Rad, S.M. Hoseini-Alfatemi, M. Sharifi-Rad, J.A Teixeira da Silva, 3 Biotech, 5, 5 (2015)

15. E.V. Banaev, G.I. Vysochina, T.A. Kukushkina, Contemporary problems of ecology, 7, 1 (2014)

16. Flora republicae popularis Romanicae, 6 (1958)

17. V.L. Komarov, Proceedings of the Main Botanical Garden, 29,1 (1908)

18. B.M. Petrov, The History of Flora and Vegetation of Eurasia (Nauka, Leningrad, 1972)

19. E.G. Bobrov, Botanical journal, 50, 8 (1965)

20. I.N. Safronova, Geobotanical mapping (2002)

21. B.A. Bykov, Publishing house of the Academy of Sciences of the Kazakh SSR, 3 (1965)

22. T.M. Lysenko, N.S. Rakov, Vegetation of Russia, 16 (2010)

23. I.N. Safronova, T.K. Yurkovskaya, Botanical Journal, 100, 11 (2015)

24. N.A. Yuritsyna, Vegetation of saline soils in the South-East of Europe and adjacent territories (2014)

25. T.M. Lysenko, IOP conf. series: earth and environmental science (2021)

26. I.N. Safronova, Proceedings of the XIV Congress of the Russian Botanical Society and the conference "Botany in the modern world", 2 (2018) 